\title{
Richard Jack—Canada’s Battle Painter
}

\author{
Lloyd James Bennett \\ Thompson Rivers University, Kamloops, Canada
}

\begin{abstract}
As a study in art history critical theory, this paper looks at the appreciation and usage of art amongst interest groups at the time of the Great War and the subsequent legacy of the work of Canada's resident war artist Richard Jack. The Canadian War Museum's recent web page described Jack's standing officer in The Second Battle of Ypres 22 April to 25 May 1915 as one who "exemplifies the courage and resolve of the inexperienced Canadians in their first major battle”. This comment showed a marked contrast to the contemporary art critic Richard Cork who described the first of the Canadian war memorials paintings as "a cliché-ridden bandaged officer ... shamelessly catering to public sentiment”. Given these disparate positions, the author attempts to explain the gulf between these points of view and subsequently make the case that art has a broad application that might make us cautious of viewing a given work without due consideration of the context of its making and future merits.
\end{abstract}

Keywords: war, art, painting, criticism, history, First World War, Canada, Jack

\section{Introduction}

As Canada emerged as a new nation into the 20th century it remained open to chronicling its history and accomplishments. The opportunity for the Dominion to show its mettle and allegiance to the British Empire came in the summer of 1914 when war was declared on Germany. Canadian Prime Minister Robert Borden notified Britain that Canada would come in supporting the war effort with an expeditionary force. After a shaky start with accommodation at the camps in the south of England, the Canadian troops fell in with the British regiments and distinguished themselves at Ypres in the spring of 1915 where the Germans first used gas in the First World War. Canadian expatriate Max Aitken, acting as eye-witness to the Front, recorded the attack and sent dispatches to Ottawa and had his newspaper friends in London repeat the slogan of Field Marshal John French that Canada had "saved the situation". After his return to London, Aitken used his Daily Express newspaper office to begin a record of Canada in the war. This branched out to include a collection of commissioned works of art. The first war artist to paint for Canada would be Richard Jack, who was made an honorary major, and asked to record the Canadians at war for the historical record of the Dominion.

\section{Canada’s Battle Painter}

Richard Jack was born at Sunderland in 1866 and studied art at the York School of Art and the South Kensington Art School; he was elected an Associate Member of the Royal Academy in 1914 and a Royal Academician in 1920. While the academy records show that he did paint historical pictures, his most productive

Lloyd James Bennett, associate professor, Department of Visual and Performing Arts, Thompson Rivers University. 
genre was the portrait: Between 1893 and the First World War he painted mostly portraits. A break from this came in 1916 when he exhibited a scene of soldiers on leave at Victoria Station returning to the Front. The picture was well reviewed in newspaper articles. At this time Jack had shown no interest or inclination to become a military painter but events in the spring of 1915 would alter the destiny of this academy artist (see Figure 1).

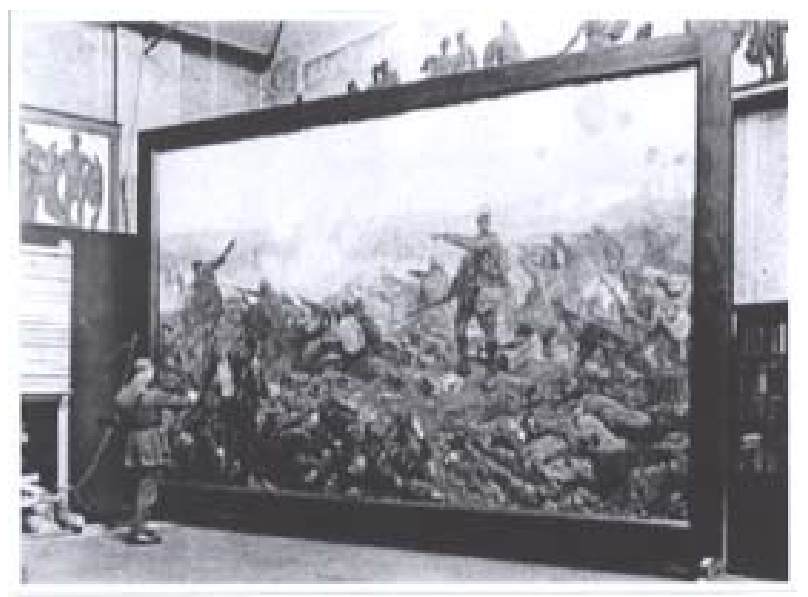

Figure 1. Richard Jack’s painting the "Second Battle of Ypres”, National Archives of Canada PA 4879.

On 22 April 1915 the Germans floated asphyxiating gas towards the Allied lines in the Ypres salient (see Figure 2). This action led the French colonial Turcos and Zouaves troops to break lines and flee in a panic of terror back into the village of Vlamertinghe. As the assault by the Germans wore on the Canadian third Brigade under Brigadier-General Robert Turner was able to hold the enemy with a hinged defence (Aitken, 1916, pp. 49-52). As this was the first time gas had been used in the war it brought a good deal of interest in the London newspapers. Field Marshal French was quoted in numerous articles on how the Canadians "saved the situation" (The Times, 1915; Observer, 1915) and forever marked the Ypres fight as a historic battle.

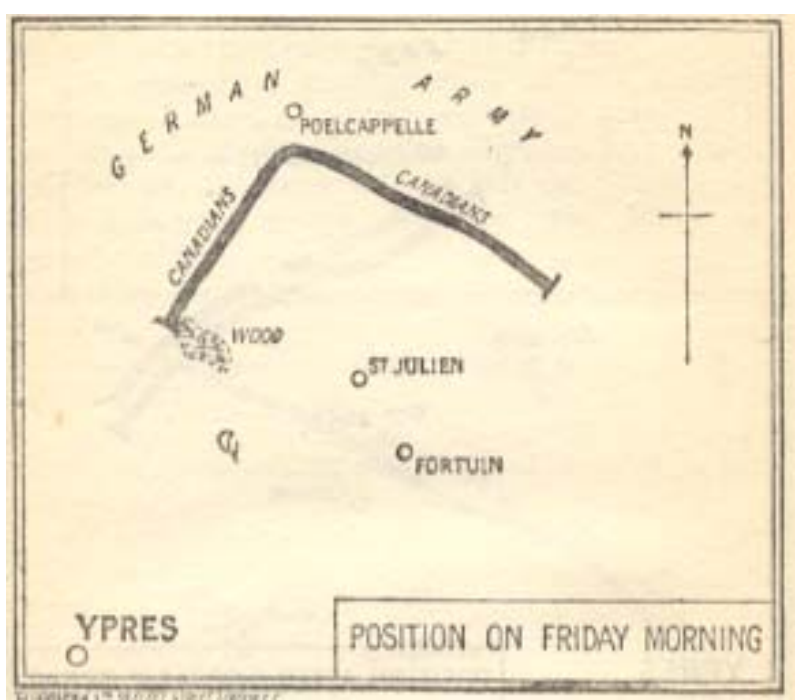

Figure 2. Map of the Ypres gas attack reproduced in Canada in Flanders.

One outcome of the heightened interest in the war was to have the Veno Drug Company of Manchester commission a painting of the battle from Royal Academy artist W. B. Wollen for the purpose of making coloured 
lithographs for sale in the public market (see Figure 3) (Tippett, 1982, p. 33). British fine art firms had a tradition of making reproductions of significant military events and the Ypres gas attack moved this battle into the legendary status of the lithographic print. Wollen surprisingly did not show the gas but a following attack in early May on the Princess Patricia’s at Frezenberg. Max Aitken, Canadian eyewitness at the Front, had written of this defence by the "Pats" under Lieut. Niven:

At 9 o'clock the shelling decreased in intensity; but it was the lull before the storm, for the enemy immediately attempted a second infantry advance. This attack was received with undiminished resolution. A storm of machine-gun and rifle fire checked the assailants, who were forced, after a few indecisive moments, to retire and take cover. The Battalion accounted for large numbers of the enemy in the course of this attack, but it suffered seriously itself (Aitken, 1916, p. 155).

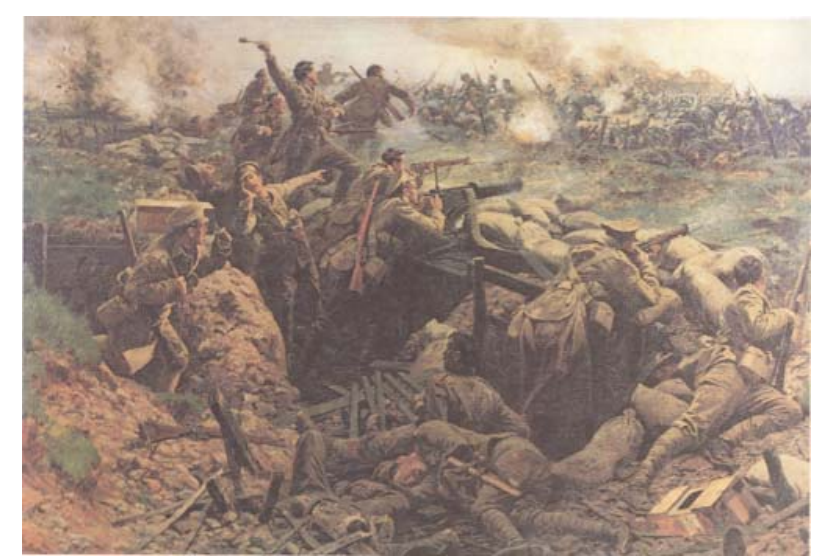

Figure 3. Canadians at Ypres, W. B. Wollen, 1916, coloured engraving after painting by W. B.Wollen, Museum of the Regiments, Calgary.

The artist had been given specific instructions as to the subject of the painting and perhaps the patron wished to honour the core of the Canadian military forces by having the first battle picture represent the Princess Patricia’s. Canada had entered a historical context by having military pictures painted of their war exploits but there was still more to be done as the expected "gas attack picture" had yet to be painted.

Aitken seized upon the idea of using academic battle pictures for his 1916 publication Canada in Flanders. One illustrator R. Caton Woodville had made a painting of the Canadian "recovering the guns" during the Ypres fighting and Aitken used the work in his war book. This began the involvement of the Officer in Charge (Aitken's next government title) to use London artists to record Canadian battles in the war. After the Veno commission Aitken moved to acquire Richard Jack making him an honorary major in December 1916. Jack was given a six-month commission to paint another canvas of the Ypres fighting and went to the Front to acquire material for the painting. Paul Konody, who became the art adviser to the Canadians, described the degree of research Jack put into the monumental work:

Though, naturally, not actually present at the fighting, Major Jack had carefully investigated and sketched the whole ground, and has spent some time with the units which took part in the engagement, collecting from officers and men all the details and facts needed for absolute accuracy. Some of the men who had been through the battle actually posed for the picture, whilst machine-guns and all manner of military accoutrements were temporarily placed at the artist's disposal, whose studio assumed something of the appearance of a battlefield. (Konody, 1918b, p. 26) 
The product of this research was the colossal $12 \times 20$ foot canvas titled in the 1919 Canadian War Memorials Exhibition catalogue, London as "The Second Battle of Ypres, 23 April to 25 May” (see Figure 4) (1919, p. 5). ${ }^{1}$ The April date is significant because it is one day after the infamous gas attack, which Jack does not appear to paint. While there is a lot of smoke, the often-described fog of yellow-green gas is clearly not part of the picture and remains the most perplexing part of Jack's work. Given the interest and the amount of research, why did Canada's first official war artist pass on the opportunity to paint the most significant war subject to date? When the critic for the Connoisseur reviewed the painting after the war, he took Jack to task for the omission:

This is a subject full of dramatic possibilities-the episode of the Canadians, suffocating and half-blinded with the poison gas, still preserving their ranks unbroken against overwhelming masses of the foe, touches on the sublime. Major Jack, however, in painting the scene, has deemed the poison gas episode of it unworthy of introduction; there is no suggestion of it. He merely shows a group of Canadian soldiers ensconced behind a trench in the foreground firing at a struggling group of Germans who are approaching in open order. The scene might have occurred in almost any battle or skirmish during the war and there is practically nothing to connect it with the second battle of Ypres. (Canadian War Memorials Exhibition, 1919, p. 110)

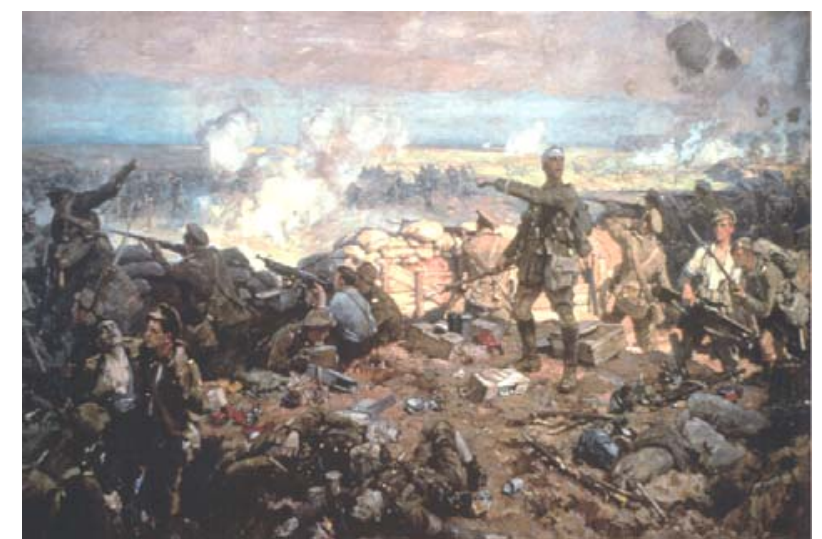

Figure 4. “The Second Battle of Ypres, 22 April to 25 May 1915”, Richard Jack, 1917, ㄷ Canadian War Museum 8179.

One can only speculate as to why Jack did not paint the expected subject but instead produced a generic scene of incidents relative to the Ypres fighting of April-May of 1915. Perhaps he did not know how to compose a composition involving a gas attack and realized it more approachable to make a studio battle of "war accoutrements" with sitters from the battle. There is no evidence of dissatisfaction on the part of Aitken who described the work in progress as “a most wonderful battle scene” (Tippett, 1982, p. 50) ${ }^{2}$ and used his Canada in Flanders account of the 22 April gas attack to document the painting in the exhibition catalogue. Perhaps the Officer in Charge was so delighted with seeing Canadian soldiers on canvas he did not want to interfere with what the artist was painting.

At one place in the painting the enemy approaches the defended parapet and in another area troops appear scattered across No-man's Land. This would tend to suggest events over a period of days beyond the gas attack where the Canadians were hit hard, but managed to hold on until relief arrived. Jack would have been aware of

\footnotetext{
1 The author has not seen the 23 April date used in any Document about the painting and Woodhouse does not use the catalogue listing for the title of Jack's painting.

${ }^{2}$ The Canadian War Memorials Committee did finally get a painting of the "gas attack" from William Roberts. See p. 7 of the Canadian War Memorials Exhibition catalogue. The picture was transferred to the National Gallery of Canada in 1921.
} 
Wollen's painting from the 1916 Royal Academy exhibition and seems to have modelled his picture on the Veno commission. The organization of the picture with its mass of foreground trench-works and high horizon recalled Wollen's painting. The gesture of Lieut. Niven and the bandaged officer in Jack's picture express similar themes, and the responding troops, who rush from the side while gazing at their commander, are reciprocal in their movements. Both Wollen and Jack had based their pictures on the traditional battle of confronting armies involving heroic action - a theme that would become increasingly diminished in modern warfare interpretation.

Jack's picture remained in the tradition of the 19th-century battle picture that promoted heroic action over absolute accuracy of detail. The focus of the picture was based upon the bandaged-headed officer leading the charge against the formidable German army. The resolute gesture of the pointing leader had many precedents in historic pictures and it became a stock pose that carried the message of self-sacrifice for the war. Images of allegorical figures leading the victorious troops populated 19th-century war pictures and by the Colonial Wars this role fell to the commander who showed the verve and the dash of leadership. This approach continued into the first military pictures of the First World War when there were still cavalry charges and pre-trench warfare stalemate. Looking back, it seems incredulous to accept that the cavalry charge could be made into German machine gun lines but that is what happened to Canada's Strathcona's Horse under Lieut. Flowerdew at the Bois de Morieul (see Figure 5). The attack saw 70 percent of the squadron killed (Canadian War Memorials Exhibition, 1919, p. 22). This fact of modern war's firepower made the heroic gesture less likely and less plausible as a believable picture motif. Yet, there were reports of just such stories as the amazing command of Colonel Buller of the Princess "Pats" “directing the gunners' fire with his walking stick" atop a parapet against the Germans (Canadian War Memorials Exhibition, 1919, p. 4).

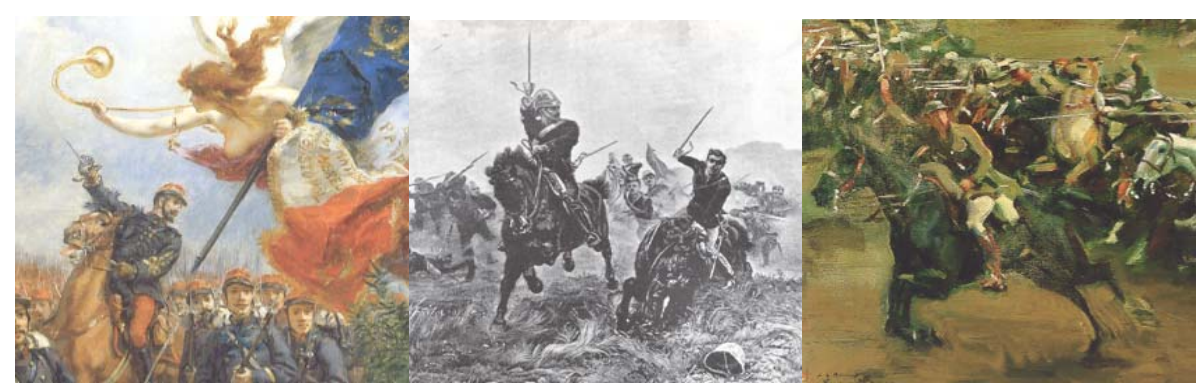

Figure 5. The military charge from France’s “victory” allegory to Canada’s Strathcona’s Horse advancing on German machines guns.

This authority of command was given more poignancy when the leader became wounded or wore the "red badge of courage”, made popular with Stephen Crane's book of the same name. Crane wrote of the wound in the American Civil War as a threshold point towards involvement in war: "At times he regarded the wounded soldiers in an envious way. He conceived persons with torn bodies to be peculiarly happy. He wished that he, too, had a wound, a red badge of courage” (Crane, 1994, p. 83). The wound showed involvement in the face of danger and heroism marked the bandaged man on his return to the breech of conflict. It set the example of selflessness in the field and identified the individual among confronting armies and made the war personal as if the outcome might hinge on the efforts of one leader. ${ }^{3}$ This would be the convenient code for the supporters of war to rally the

\footnotetext{
${ }^{3}$ While Canada in Flanders mentions a number of wounded men returning to battle, there does not seem to be one incident that would account for the bandaged-headed man in Jack's picture.
} 
forces in the field and on the home front to consider each person's contribution to the common goal of military victory. The difficulty came when the heroic gesture became viewed as a cliché carrying a false or "studio sentiment" that had lost it power to move the viewer to war's lofty ideal of sacrifice.

In Jack's battle picture, the urgency of response to war's situation was further laid out in the sandbagged "trench fort" where the besieged troops made their stand with "raised rifle butts" against the enemy amid the chaos of their situation. While there were a number of wounded officers who returned to the Ypres fighting, there did not appear to be an obvious historical figure for the leader in Jack's picture and would therefore appear to be a "type" representing the courage of the largely inexperienced Canadian Division. Art critic Konody felt he had to apologize for the gesture of the standing officer when he reviewed Jack's painting in a Colour Magazine article calling the gesture a "theatrical pose ... that clings to the academic tradition of the battle picture" (Konody, 1918a, p. 30). Konody's comment, no doubt, disguised his embarrassment that Jack would paint such a cliché in a contemporary picture, but it should be remembered that Jack was attempting to make a history painting and felt obliged to present the ideal of self-sacrifice that was at the centre of great battle pictures. The goal of creating a picture that would convey heroism for a nation with no visual record of military endeavour would not be out of place in the context of the commission.

The debris of abandoned rifles and ammunition boxes amid the dead of the "last stand" conveyed the ferocity of the fighting at the Ypres attack. One figure has just received a headshot while another soldier helps a wounded comrade to safety beside two discoloured corpses. What was unusual about these dead soldiers was that they were not censored by the War Office for showing the death of Allied troops, which was rigorously enforced after the August 1914 passing of the Defence of Realm Act so as to not show soldiers in any way that could be used for propaganda purposes by the enemy. When C. R. W. Nevinson revealed two matter of fact corpses in this painting "Paths of Glory” (1917) he was censored for showing dead British troops. The artist complained that he was only showing the casualties of war, and when his voice found no support at the War Office, he voluntarily covered the exhibited painting with his own paper banner labelled "censored" to protest the treatment by British officials of his picture.

It is not clear why the War Office did not censor Jack's picture before it was reproduced in Canada in Khaki, but perhaps these Ypres corpses were considered as history painting and therefore did not apply to the contemporary ban. Further, there was a noted cynicism in Nevinson's title that no doubt annoyed the War Office that not everyone was behind continuing the war by 1917. The Somme Offensive in the summer of 1916, where over 57,000 casualties occurred on the first day of July, brought increased pressure to abandon the apparent slaughter in Europe. Whereas Nevinson's picture brought home the realities of what the war had become-a great destruction—Jack's picture continued to paint the glory of war largely based upon the wishes of his patron who wanted to use art to "make history" for the young Dominion. This was the first goal behind the Canadian War Records Office, to make a record of Canadians in the war and promote Empire support for the conflict.

\section{War Art in Context}

If Max Aitken was eager to have the services of academician Richard Jack to paint battle pictures for the Canadian government, the situation with the British government war art scheme was different. The first official war artist to be sent to the Western Front for the British was the printmaker Muirhead Bone. Bone was a member 
of the New English Art Club and specialized in scenes of ruins and was known to have a reputation for his graphic images in Europe. Wellington House, the division of the British government in charge of influencing neutral countries, thought the artist's rendering of war ruins would prove advantageous in publications to gain support for the war effort. A series of Wellington House pamphlets began after Bone's trip to the Somme in the summer of 1916 (see Figure 6) and eventually were published in a volume called The Western Front (Bone, 1917).

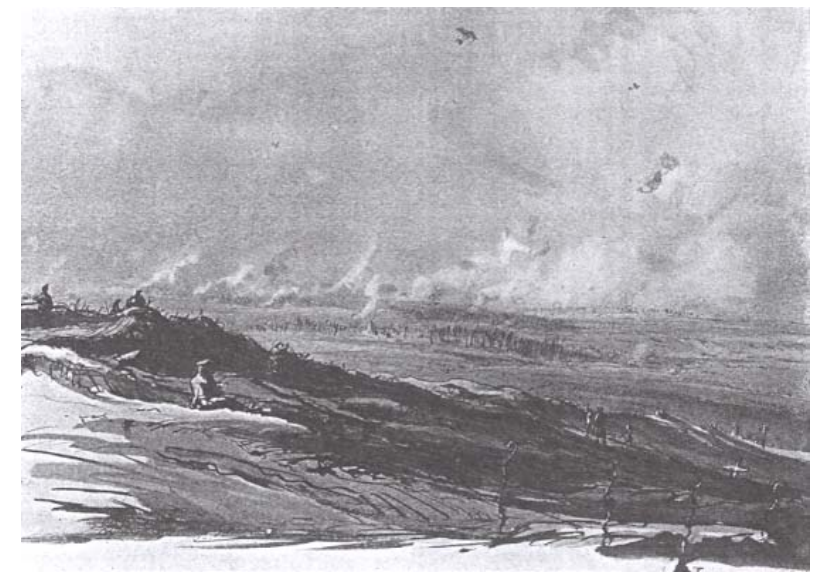

Figure 6. “The Battle of the Somme”, Muirhead Bone, 1916.

At the core of Wellington House's interest in war art was propaganda and how it could be used to persuade neutral countries (especially the United States) to the merits of British civilization. Charles Masterman, the head of the bureau, recognized that writers and artists could show their support for the war by their very works that spoke of the worldwide respect for British culture. Writers such as Arnold Bennett, G. K. Chesterton, Sir Arthur Conan Doyle, John Galsworthy, Thomas Hardy and Rudyard Kipling were cited as offering their "services" for the war effort (Report of the Work of the Bureau, 1915, p. 1). In this vein of cultural progression visual artists were also to be included as exemplars of contemporary culture.

This currency would not, however, be found at the Royal Academy, an institution associated with tradition, but at societies like the New English Art Club and with Slade School graduates who adopted the more progressive art styles of Europe. Indeed when Arnold Bennett, the novelist, became a member of the British War Memorials Committee he almost bragged that he was able to keep academy artists out of the war commissions: "The object of the Committee is to procure a complete record of the whole blooming war in paint, ink and sculpture. I have succeeded in turning down all R. A. members, except Clausen. Some feat, believe me!” (Bennett, 1970, p. 54). The division between the Royal Academy artists and the British government war art advisers was especially strong having its roots in the development of modern British art.

The dominant style of 19th-century British art had been the Pre-Raphaelitism of the Royal Academy but this realist-narrative art had been challenged with the "art for art's sake” movement that had been planted in London with James Whistler, taking institutional form in the New English Arts Club. It was at the New English that the contemporary ideas on painting such as Impressionism found expression on the gallery walls of London. With this contemporary development in London art the dominance of the Royal Academy became challenged and a division grew between the supporter of traditional art and the more progressive approach. It would be in this milieu that the government commissions for war art began at Wellington House in 1916. Most of the advisers that 
Masterman brought on board in the bureau were fine art men who had little interest in academy art and traditional military painting. Their bias lay with the contemporary artists and graduates of the Slade School and exhibitors of the New English were given preference over the battle painters of Saint John's Wood.

A further reason for contemporary art critics to dislike academy artists was their association with the London "weeklies". To earn a living outside of their academy work a number of RAs became "specials" or war correspondents by following the British armies in the Colonial Wars making sketches to be sent back to London to be used as illustrative material (see Figure 7). These became popular images and spoke of the romance of overseas war, but to most art critics the works were considered as sensational, illustrative material appealing to the uneducated masses. This view of the academy artists as illustrators followed them with their exhibited canvases. Observer art critic Konody in his 7 May 1916 article "War Pictures at the RA" wrote of the battle pictures as a "kind of painted supplement to official despatches and newspaper reports" (Konody, 1916b). What these works lacked, according to Konody, was the experience of being in the war situation that led to such dull performances by “stay-at-home artists from descriptive material in their comfortable studios” (Konody, 1916a).

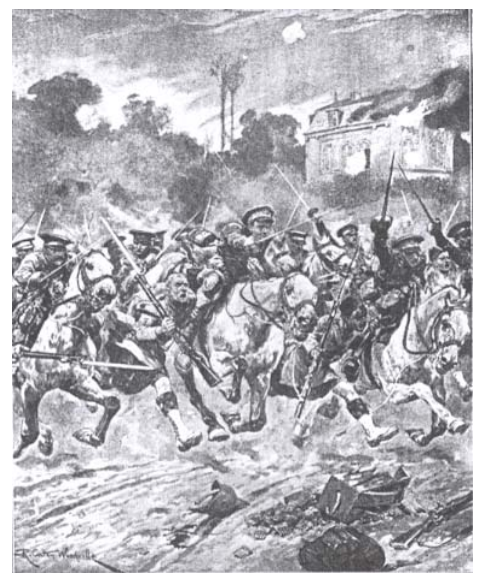

Figure 7. R. Caton Woodville's work in the The Illustrated London News.

One artist to break this second hand reporting on war was Eric Kennington who had served with 13th Battalion of the London Regiment in the winter of 1914. In 1916, he produced a series of drawings from an unofficial visit to France and exhibited the work at the Goupil Galleries in April 1917 to much acclaim. Equally impressive was his oil on glass painting The Kensingtons at Laventie, to which Wellington House adviser Campbell Dodgson extolled the value of the painting in the bureau publication British Artists at the Front:

Here was a soldier painting soldiers, with skill of hand, memory undimmed, and a heart moved deeply by share and experience of suffering and hardship. The kit and arms were just what he and his comrades had worn and carried, not the studio properties of the military painter in St. John's Wood. We shall never again have patience with academic military painting of the nineteenth century professional type now that young men, who have fought before they painted, have shown us what war is. (Dodgson, 1918, n.p.) ${ }^{4}$

This comment summed up the view that military art had become divorced from reality and needed to be made more relevant by having war artists on the scene experiencing war first hand to be able to produce picture

\footnotetext{
${ }^{4}$ First World War Artist Archives, Imperial War Museum. Konody was equally impressed with Kennington’s picture: “no amount of experience collected at second hand could make up for experience”. See “Art and Artists: Goupil Galleries” (1916a).
} 
with any relevancy. The problem this would present for the official war artist was how one could get close enough to the fighting to recover this "truth" of modern war.

One way to report the war was to do it from experience. As many of the future official war artists had served at the Front, they could use their exposure to war, as Kennington had done, to make pictures about the conflict. Others like Muirhead Bone could only draw behind the lines of the camp scenes or record the ruins as the Allied forces moved into new territory. Beyond reportage the official war artist could internalize the war and express his response with drawings from the devastated landscape as Paul Nash had done on his assignments in Flanders. Nash had joined the Artists Rifles at the beginning of the hostilities, and managed to produce and exhibit drawings of the Ypres salient at the Goupil Galleries in July of 1917. This exhibition brought exposure to the young artist who was able to use it to gain a commission from Masterman. Francis Hopford, editor of Land and Water, in a letter of support cited Nash's Goupil show: "The Exhibition he had at the Goupil Galleries this summer was in my opinion, quite one of the best war exhibitions that have been held. It was only a small one, but you came away from it with a much better understanding of German brutality and of the needless horror and destruction which German armies are committing under orders in the occupied territories.” (Hopford, 16 August 1917). The editor crafted the letter to describe the drawings in terms that suggested their anti-German references, and thereby revealed Nash's potential as a government war artist. Others also helped to identify Nash's artistic abilities: Fellow artist William Rothenstein remarked that while Nash was not a figure artist, he "is extremely imaginative" and "has a very fine landscape vision” (Rothenstein, 1917). Dodgson was more cautious as he saw Nash's work as "decidedly post-impressionist, not cubist, but decorative” (Dodgson, 1918). While the work might not have a public following, the adviser thought there would be interest by other artists and those who followed "more modern developments" (Dodgson, 1918). This was a remarkable admission on the part of Dodgson to suggest that a government artist could work at pictures devoid of mass appeal, which showed that the basis of the British approach to propaganda art had at its core the notion of excellence in contemporary culture.

If the British war artists were responding to war contemporaneously, the Canadian mission had been from the first commission to make a record of Dominion involvement in the war. The context from this position was historical and therefore required recreation of significant battles of recent history. Further, the bias against the academy artist was not in place with Aitken and the Canadians because they were on the whole outside of the development of modern ideas in painting. It was not until Konody was taken on as artistic adviser to the Canadian War Memorials Fund in the summer of 1917 that the Canadian commissions took on a contemporary flavour. The precedent of securing historic battle pictures of the Canadian forces was already in place and so the context of what was collected under Robert Borden's government remained broader than what would be collected for the British government.

Under the direction of Aitken, Konody looked to fill the historical need of Canadian military pictures and francophone inspired works to appease the Quebec war dissenters who questioned or disapproved of Canada's involvement in an overseas war. In fact, the first commissions Konody handed out were two paintings of French Canadian subjects. Academy painter Edgar Bundy was to record the history of the founding of Quebec by Champlain and the French Canadians landing in France during the current war. Bundy recorded eight officers in his "Landing of the First Canadian Division at St. Nazaire" (see Figure 8) (1918), which showed a rousing entry into the town by a military pipe band. The landscape, with its misty aspects of the French coast, added to the spirit 
of adventure the picture wished to convey. Today it hangs in the Canadian Senate Chamber, and with its esprit de corps and stormy skies, it appears as a work more of the 19th-century than modern war. Still the picture recalls the adventurous spirit, a factor for enlistment of many a volunteer, and so remains a legitimate sentiment of the early days of the Great War.

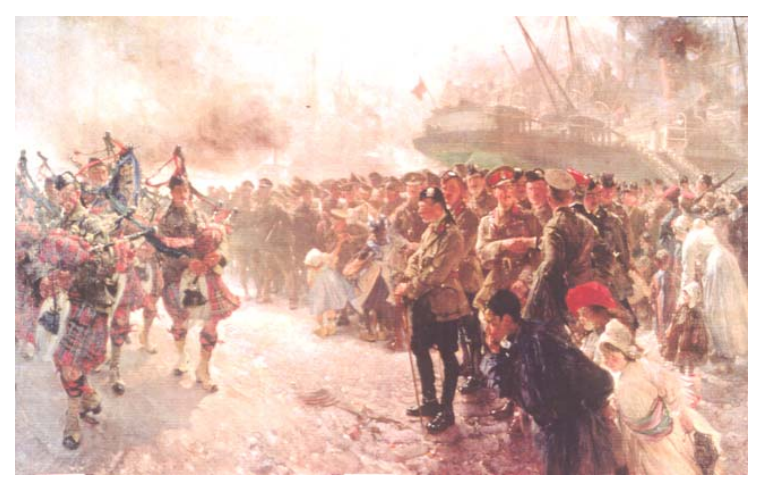

Figure 8. “Landing of the First Canadian Division at Saint-Nazaire”, Edgar Bundy, c. 1918, Canadian War Museum 8121.

\section{A Modern Battle}

By mid-October of 1917, Jack was given a nine-month extension of his commission and went on to his second major work for the Canadian War Memorials Fund, “The Taking of Vimy Ridge” (see Figure 9). This work focused on the massive shelling of the ridge that took place on Easter Monday, 9 April 1917 during a driving sleet: "By 6:15 am, the 1st and 2nd Divisions had battled their way to the Black Line, through well-sighted machine gun fire and often times hand-to-hand combat” (Collectionscanada.ca, n.d.). It was to be another battle history that Jack had taken on, but the supply of photographs and details of the fight was now plentiful as he set to reconstruct the second of the historic Canadian victories of the war.

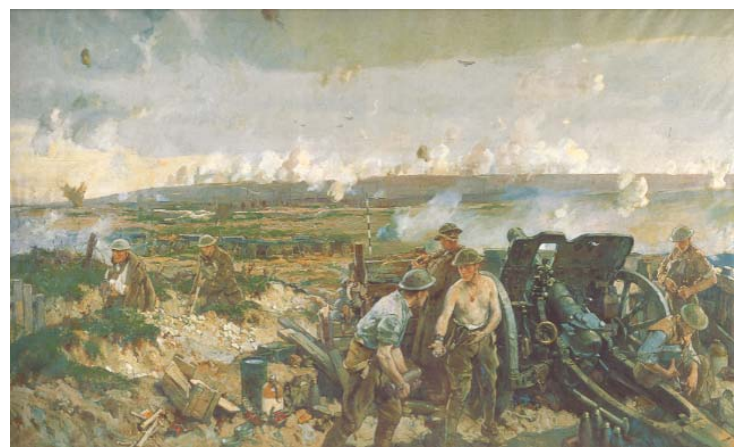

Figure 9. “The Taking of Vimy Ridge, Easter Monday, 1917” Richard Jack, 1919, 드 Canadian War Museum 8178.

No doubt aware of Konody's feeling for heroic gestures, Jack composed a picture completely in sympathy with what he might have witnessed should he have been at the event. The painting focused on a Canadian battery where men work in unison passing the shells to fire their gun at the ridge, which appears under a curtain of smoke from the barrage. The landscape recalled the flat features of the many photographs taken of the area, which Jack enlivened with a considered breadth of earth tones. The sky remained a patchwork of smoke and shelling suggesting, but not revealing, the power of the massive artillery fire. The amount of ammunition used during the 
Vimy assault (38,250 tonnes) was identified as the main reason for the Canadians claiming the ridge. The Illustrated War News printed the often used (with corpses removed) Canadian War Records Office photograph of the Canadians advancing at Vimy Ridge over a two-page spread with the commentary (see Figure 10):

With such completeness and thoroughness had the artillery done their work on Vimy Ridge among the German entrenchment and belts of barbed-wire entanglement, that, as far as outlying obstacles remained, the infantry of the Canadian attack had in most places little more than a "walk over". 5

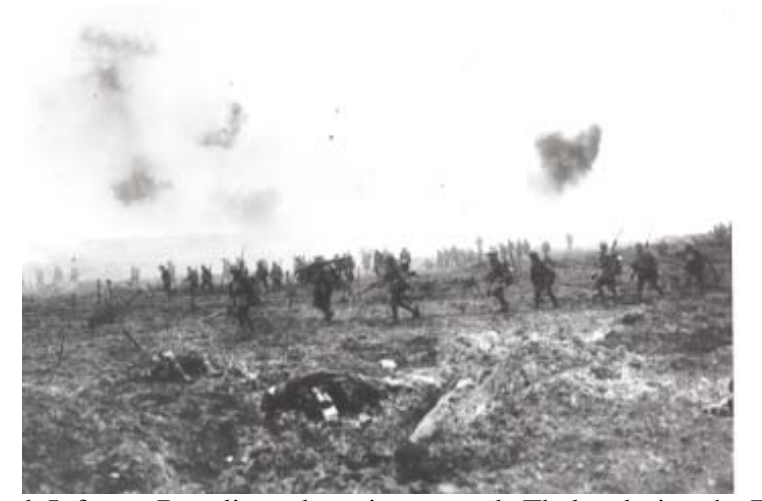

Figure 10. Twenty-ninth Infantry Battalion advancing towards Thelus during the Battle of Vimy Ridge, France, Ivor Castle, 9 April 1917, National Archives of Canada PA1020.

Praising the effectiveness of the artillery at the expense of the infantry had been the model of the press since the misreporting of the 1916 Somme Offensive, and it had slighted the very difficult work that had to be done by the Canadian troops on the ground, including hand-to-hand fighting. Still Jack had represented well the very significant feature of barrage shelling and the now-experienced troops who ran the business of the war machines with routine skill. There was a new focus in Jack's second battle picture, rather than individual heroics, there emoted a kind of unit professionalism or what Konody had called "self-obliterating devotion to duty". Jack had worked out of the clichés of heroic gestures and raised rifles butts, but had done it within his academic picture tradition by looking to the contemporary gestures of the troops who ran machine-age war. He had shown that battle scenes still had a place in modern war art and that war sacrifice could be represented by routine performance of duty. The academy painters had shown that they would not be limited to the established methods of military art, but had the flexibility to introduce new ideas to reflect contemporary war.

\section{Conclusion}

Richard Jack moved to Montreal in 1930 and sought new opportunities in painting from the country that had made him its resident war artist. While considered by some to be an anachronistic artist, his work during the First World War holds up as reportage of significant events in the fighting and, to a greater or lesser extent, the exponent of the notion of the sacrifice that proves time and again not to be an insignificant factor in the attempt to be victorious in war. As to art criticism, when Paul Konody was taken on as the Canadian war art adviser he became more open to the military picture and his theories on the narrow concerns of modern painting practices broadened to recognize the merits of a historical record in art. Upon reviewing the war memorials he wrote of

\footnotetext{
5 “Canada’s Never-to-be-forgotten Achievement—-the Victorious Assault on Vimy Ridge Position” (25 April 1917, pp. 154, 46; pp. 20-21). For a discussion of the London press and battle reporting, see Sillars (1987).
} 
Jack’s Ypres picture as standing “unrivalled among British battle paintings” (Konody, 1918b, p. 26), which had been a significant move from how he had looked at war art in his earlier exhibition reviews. As for Richard Cork's criticism that Jack’s picture was "catering to public sentiment” (Cork, 1994, p. 204), one only has to look at the propaganda mission the Germans unleased to influence neutral countries to their side in the first years of the war to appreciate this as a weapon of modern warfare. To use images of recent history to assist a nation at the centre of a world war is not unthinkable. All art has at its core the mission to convince and Jack's pictures occupy an aspect of art that looks to increase national pride and record its military history. In this we might recognize the value of art that transcends temporal styles for a larger societal perspective that includes looking back to our war effort.

\section{References}

Aitken, Sir M. (1916). Canada in Flanders: The official story of the Canadian expeditionary force (vol. 1). London: Hodder and Stoughton.

Bennett, A. (1970). Letters of Arnold Bennett. J. Hepburn (Ed.). London: Oxford University Press.

Bone, M. (1917). The western front: Drawings by Muirhead Bone. London: War Office.

Canada saves the day. (1915, April 25). Observer, n.p..

Canadian war memorials exhibition catalogue. (1919). London: Canadian War Records Office.

Canvas of War: Masterpieces from the Canadian war museum. (2000). The second battle of Ypres, 22 April to 25 May 1915. Retrieved from http://www.warmuseum.ca/cwm/canvas/tre/cwc104e.html

Collectionscanda.ca. (n.d.). The battle of Vimy Ridge, April 9-12, $1917 . \quad$ Retrieved from http;//www.collectionscanda.ca/firstworldwar/051806/0518060401_e.html

Cork, R. (1994). A bitter truth: Avant-garde art and the Great War. New Haven and London: Yale University Press.

Crane, S. (1994). The red badge of courage. London: Penguin, [Appleton 1895].

Dodgson, C. (1918). IV Eric Kennington. Country Life. London: no publisher.

Dodgson, C. (1917-1918). First world war artist archives: 267 A/6, Paul Nash, Dodgson to Masterman, 18 October 1918. London: Imperial WarMuseum.

First world war artist archives. (1917-1918). London: Imperial War Museum.

Graves, A. (1906). The Royal Academy of arts: A complete dictionary of contributors and their work from its foundation in 1769 to 1904 ( vol. 4). London: Henry Graves and George Bell.

Hopford, F. (1917-1918). First world war artist archives: 267 A/6, Paul Nash, Hopford to Buchan, 16 August 1917. London: Imperial WarMuseum.

Illustrated War News. (1917, April 25). “Canada’s never-to-be-forgotten achievement-The victorious assault on Vimy Ridge position," 20-21.

Konody, P. (1916a, May 14). Art and artists: Goupil gallery. Observer, n.p..

Konody, P. (1916b, May 7). Art and artists: War pictures at the RA. Observer, n.p..

Konody, P. (1918a). Canadian war memorials number, Colour, 30(September), 25-41.

Konody, P. (1918b). The Canadian war memorials fund: Its history and objects. Canada in khaki, 2, 25-28.

Report of the work of the bureau established for the purpose of laying before neutral nations and the dominions the case of Great Britain and her allies. (1915). INF 4/5. Kew: Public Records Office.

Rothenstein, W.(1917-1918). First world war artist archives: 267 A/6, Paul Nash, Rothenstein to Dodgson, 11 September 1917. London: Imperial WarMuseum.

Sillars, S. (1987). Art and survival in First World War Britain. London: Macmillan.

The bonds of empire. (1915, May 1). The Times, n.p..

The Canadian war memorials exhibition. (1919). Connoisseur, 53(210), 110.

Tippett, M. (1982). The history of the Canadian war memorials scheme as a study of patronage and visual record of the Great War (Ph.D. dissertation, University of London).

Woodhouse, R. F. (1968). Check list of the war collections of World War I, 1914-1918 and World War II, 1939-1945. Ottawa: The National Gallery of Canada. 